\title{
Wpływ zadłużenia publicznego na dynamikę wzrostu gospodarczego w krajach Europy Środkowo-Wschodniej
}

Zbigniew Karmela*

\section{Wstęp}

Oddziaływanie długu publicznego na wzrost gospodarczy oraz wysokość bezpiecznego poziomu zadłużenia po następstwach kryzysu finansowego w USA w 2007 r. stało się przedmiotem ożywionej dyskusji zarówno wśród ekonomistów, jak i polityków, a późniejsza dekoniunktura gospodarcza przyczyniła się do podjęcia działań zapobiegawczych w zakresie polityki monetarnej oraz fiskalnej. Wiązało się to często ze znacznym zwiększeniem zadłużenia publicznego lub nawet wystąpieniem kryzysu finansów publicznych w niektórych krajach, w tym Europy Środkowo-Wschodniej (Litwa, Łotwa). Znaczący wzrost obciążeń budżetowych skłania do refleksji nad tym, czy bezpieczny poziom długu, zapewniający stałe tempo wzrostu gospodarczego, został już przekroczony.

Do zasadniczych celów badawczych artykułu należą ocena możliwości wpływu wysokości zadłużenia publicznego na dynamikę wzrostu gospodarczego w wybranych krajach oraz określenie stopnia ryzyka nadmiernego zadłużenia. Przeprowadzone analizy empiryczne koncentrują się na weryfikacji współistnienia zjawisk dużego długu publicznego i niskiego wzrostu PKB per capita, a także na określeniu, czy między tymi wskaźnikami zachodzi związek przyczynowo-skutkowy. Szczególną uwagę poświęcono maksymalnej dopuszczalnej wielkości zadłużenia w relacji do PKB. Warto jednak zaznaczyć, że istnieje wiele ograniczeń dotyczących badania zależności między tymi zmiennymi, a ekonomiści niestety nie są zgodni co sposobu, w jaki należy to robić. Ponadto istnieje pewne prawdopodobieństwo, że w krajach, które przekroczyły krytyczny poziom długu, wzrost gospodarczy nadal będzie stosunkowo duży. Przykładem takiej sytuacji może być brak załamania się wzrostu gospodarczego w USA po przekroczeniu wskazywa-

* Zbigniew Karmela - magister, Uniwersytet Łódzki, Wydział Ekonomiczno-Socjologiczny, Katedra Makroekonomii, zbigniewkar@gmail.com. 
nej przez Reinhart i Rogoff 90-procentowej granicznej relacji zadłużenia do PKB. Autor jest świadomy tych problemów, dlatego w niniejszym opracowaniu zwrócono uwagę na różnicę pomiędzy współistnieniem wysokiego długu publicznego i niskiego tempa PKB a charakterem związku przyczynowo-skutkowego między tymi kategoriami ekonomicznymi. W celu zminimalizowania błędu w kalkulacji teoretycznego granicznego poziomu długu zastosowano cztery alternatywne modele ekonometryczne. Należy jednak pamiętać, że wyliczone graniczne poziomy udziału zadłużenia mają charakter poglądowy, a nie wiążący, i są uzupełnieniem dyskusji na temat ważnego problemu skutków występowania długu publicznego.

$\mathrm{Na}$ początku artykułu zostały przestawione wybrane opisane w literaturze przedmiotu dotychczasowe wyniki badań, uwzględniające także wnioski płynące $\mathrm{z}$ dwóch metaanaliz literatury. W dalszej części omówiono wątpliwości metodyczne związane $\mathrm{z}$ badaniem wpływu zadłużenia publicznego na tempo wzrostu gospodarczego. W ostatniej części opracowania skupiono się na empirycznej weryfikacji zależności między opisywanymi zjawiskami. Weryfikację statystyczno-ekonometryczną podzielono na dwie części. Pierwsza z nich to analiza statystyk opisowych, mająca za zadanie dowieść, czy wysoki dług publiczny jest skorelowany z niskim wzrostem PKB. W drugiej części opisano metodologię oraz wyniki estymacji czterech modeli ekonometrycznych dla danych przekrojowo-czasowych, pochodzących z obserwacji (w latach 1996-2017) 11 krajów Europy Środkowo-Wschodniej należących do Unii Europejskiej. Estymacje te były również podstawą wyliczenia różnych poziomów maksymalnej dopuszczalnej wielkości zadłużenia publicznego.

\section{Przegląd literatury}

Rozważania teoretyczne nie dają jednoznacznej odpowiedzi na pytanie o występowanie zależności pomiędzy długiem publicznym a wzrostem PKB. Co więcej, badacze tego zagadnienia są dalecy od konsensusu. Wyniki niektórych prac empirycznych wskazują na negatywny wpływ zadłużenia publicznego na tempo wzrostu PKB. Na podstawie innych można wywnioskować, że taka zależność nie istnieje. Występują również opracowania, w których dowodzi się, że dług publiczny nieliniowo wpływa na tempo wzrostu gospodarczego, które ostatecznie zależy od dodatkowych czynników. Do zmiennych różnicujących oddziaływanie wysokości zadłużenia publicznego na dynamikę PKB zalicza się m.in. wysokość udziału długu publicznego w PKB, poziom rozwoju ekonomicznego danego państwa, a także występowanie kryzysów zadłużenia we wcześniejszym okresie (Siwińska-Gorzelak 2015). W opracowaniach wskazujących na nieliniową relację między długiem a wzrostem zwykle stosuje się czynnik różnicujący w postaci progu zadłużenia, wprowadzając do równań regresji zmienne zero-jedynkowe lub umieszczając kwadrat zadłużenia publicznego. Stosując pewne ustalone progi, można określić 
graniczną wartość poziomu zadłużenia, w przypadku którego zmienia się charakter bądź intensywność zależności pomiędzy omawianymi zmiennymi. Niektórzy naukowcy zauważają, że dług może mieć pozytywne skutki, ale tylko wtedy, gdy jego poziom jest niewielki.

Pierwsze studia empiryczne koncentrują się na zależności liniowej. Badacze tacy jak Diamond (1965), Modigliani (1961), Saint-Paul (1992), Blanchard (1985), Barro (1990), a później także Aizenman (2007), bazując na neoklasycznych endogenicznych modelach wzrostu gospodarczego, pokazują, że w długim okresie dług - niezależnie od tego, jaki jest on duży - determinuje spowolnienie tempa wzrostu gospodarczego. Jest to spowodowane mniejszą akumulacją kapitału będącą następstwem obniżonej stopy inwestycji. Ekonomiści Tanzi i Chalk (2000), Gale i Orszag (2003), Laubach (2009) oraz Baldacci i Kumar (2010) dowodzą, że skutki rosnącego zadłużenia publicznego, ze względu na tzw. efekt wypychania, są negatywne. Wzrost zadłużenia prowadzi do podwyższenia rynkowej stopy procentowej, a w konsekwencji - do zmniejszenia inwestycji prywatnych. Wysoki odsetek długu - jak zauważają m.in. Teles i Mussolini (2014) - może także zniechęcić zagranicznych inwestorów, którzy zaczną zmniejszać rozmiary inwestycji w zadłużonych krajach. Kumar i Woo (2010) stwierdzają, że wysoki poziom długu publicznego ma negatywny wpływ na tempo wzrostu gospodarczego w 5-letnim horyzoncie czasowym. Naukowcy ci, stosując wielowymiarową analizę, dowodzą, że wzrost relacji długu publicznego do PKB o 10 punktów procentowych (pp.) skutkuje spowolnieniem tempa wzrostu gospodarczego o $2 \mathrm{pp}$. Schclarek (2004) natomiast dokonał rozróżnienia względem rozwoju gospodarczego poszczególnych państw. Autor konkluduje, że istnieje istotna negatywna zależność pomiędzy długiem a wzrostem wśród krajów rozwijających się, która jednak nie pojawia się w przypadku krajów rozwiniętych.

$\mathrm{Na}$ nieliniową relację między zadłużeniem publicznym a wzrostem gospodarczym wskazują często przywoływane przez innych autorów badania Reinhart i Rogoff (2010). Autorzy, agregując dane dla 44 krajów i używając szeregów czasowych sięgających w niektórych przypadkach nawet XVII w., stwierdzili, że wpływ zadłużenia publicznego na tempo wzrostu gospodarczego krajów rozwiniętych jest niewielki, pod warunkiem, że omawiana relacja nie przekroczy $90 \%$. Po przekroczeniu tego progu następuje spadek tempa wzrostu gospodarczego o 1-4 pp. Rozpatrując dane dotyczące krajów rozwijających się, wyliczono, że w przypadku 60-procentowego progu relacji zadłużenia publicznego do PKB średni wzrost PKB jest o 2 pp. niższy. Studia, w których wyliczono krytyczne wartości progowe dla pewnych poziomów długu, przeprowadzili również Checherita-Westphal oraz Rother (2012), Cecchetti i in. (2011), Baum i in. (2013), Mencinger i in. (2015). Z badań tych wynika, że maksymalna dopuszczalna wielkość zadłużenia wynosi 66-96\% (w przypadku krajów rozwijających się 40-60\%) (Mencinger i in. 2015). Znacznie wyższe wartości graniczne pojawiają się w opracowaniu Karadama (2018), zwłaszcza odnośnie do krajów rozwijających się, 
w przypadku których dopiero po przekroczeniu $88,2 \%$ poziomu zadłużenia ma nastąpić spadek tempa PKB. Próg bezpiecznego zadłużenia krajów rozwiniętych to $106,6 \%$. Afonso i Jalles (2013) oraz Chen i in. (2016) nie uwzględnili w swoich badaniach poziomu rozwoju gospodarczego. Przeprowadziwszy estymację panelową odpowiednio dla 155 i 65 krajów z obu tych grup, doszli oni do wniosku, że dług publiczny zaczyna negatywnie wpływać na wzrost gospodarczy po przekroczeniu ok. 60\%. Caner (2010), przebadawszy 101 krajów, stwierdził, że po przekroczeniu $77 \%$ relacji długu do PKB wzrost gospodarczy zaczyna spowalniać, jednak w większym stopniu dotyczy to krajów rozwijających się. Wartości znacząco inne od najczęściej spotykanych wartości krytycznych uzyskał Egert (2015), który pokazał, że dług publiczny zaczyna determinować spadek tempa wzrostu PKB już po przekroczeniu 20\%. Autor ten zwraca jednak szczególną uwagę na trudność wyliczenia wiarygodnych wartości progowych, argumentując, że zależy to od przyjętego modelu oraz zakresu wprowadzonych danych. Gómez-Puig i Sosvilla-Rivero (2015) przeanalizowali dane dotyczące krajów strefy euro, jednak nie przeprowadzili analizy panelowej dla całej grupy, tylko dla pojedynczych krajów, odrzucając przy tym estymacje, które nie wykazały przyczynowości w sensie Grangera.

Na podstawie tak skonstruowanych wyliczeń okazało się, że - jeśli występowała przyczynowość - próg powyżej którego wielkość długu była niekorzystna dla wzrostu PKB wynosił 56-103\%. W późniejszym badaniu tych samych naukowców (2017 r.) progi bezpieczeństwa dla peryferyjnych krajów strefy euro oscylowały między $40 \%$ a $50 \%$. W przypadku krajów bardziej rozwiniętych były one niewiele większe i wyniosły maksymalnie $61 \%$. Rozszerzonej analizy wpływu długu na wzrost w krajach rozwijających się dokonali Cordella, Ricci i Ruiz-Arranz (2005), którzy oddzielnie badali grupę HIPC (ang. Heavily Indebted Poor Countries). Według tych ekonomistów wpływ długu na wzrost PKB w krajach rozwijających się, ale nienależących do grupy HIPC, jest nieliniowy i zmienny w zależności od wysokości długu. Wyróżnia się tu dwa progi - wraz z przekroczeniem pierwszego, na poziomie między $10 \%$ a $30 \%$, tempo wzrostu zaczyna spadać. Natomiast po przekroczeniu drugiego progu, który wynosi ok. $80 \%$, dalsze przyrosty długu nie mają znaczącego wpływu na tempo wzrostu PKB. W przypadku krajów z grupy HICP autorzy nie zauważyli istotnego negatywnego wpływu długu na dalsze tempo wzrostu PKB. Uważa się, że powodem tych różnic są bardziej preferencyjne warunki kredytowania zapewniane tym krajom przez instytucje międzynarodowe.

Bilan i Inhatow (2014), Mencinger i in. (2014) oraz Bilan (2015) przeprowadzili badanie interesujące w kontekście niniejszego opracowania, ponieważ uwzględnili podobną grupę krajów. Na podstawie wyliczeń autorów okazało się, że dla krajów członkowskich UE rozwiniętych gospodarczo bezpieczny poziom zadłużenia zamyka się w przedziale 80-99\%, natomiast w przypadku krajów rozwijających się ten odsetek był znacznie niższy i wyniósł między $42 \%$ a $55 \%$. 
Wyraźne obniżenie bezpiecznego poziomu zadłużenia krajów rozwijających się było argumentowane mniejszą wiarygodnością dla inwestorów, większą podatnością na wstrząsy gospodarcze oraz większą zależnością od zewnętrznych transferów kapitałowych.

Panizza i Presbitero (2013) w swoim późniejszym opracowaniu zwracają uwagę na problem endogeniczności oraz odwrotnej przyczynowości. W badaniu obejmującym kraje OECD twierdzą, że przeprowadzenie regresji dla wartości zadłużenia oraz wzrostu PKB daje typową ujemną zależność pomiędzy tymi zmiennymi, często występującą w literaturze przedmiotu. Jednak po zastosowaniu zmiennej instrumentalnej silnie skorelowanej z wielkością długu publicznego zależność wzrostu PKB od długu przestaje być istotna. Eberhardt (2017), wykorzystując analizę kointegracyjną obejmującą 27 krajów, również nie znalazł dowodów na oddziaływanie długu publicznego na wzrost PKB. Co istotne autor ten, podobnie jak Reinhart i Rogoff, wykorzystał w swoim badaniu bardzo długie szeregi czasowe, sięgające nawet $1800 \mathrm{r}$.

Celem przedstawienia niniejszych rozważań empirycznych, które są jednymi $\mathrm{z}$ wielu istniejących w literaturze - było stworzenie jedynie pewnego uogólnionego przeglądu, a nie wyczerpanie analizowanego tematu. Przytoczenie większości z nich znacząco przekroczyłoby ramy niniejszego opracowania i zapewne również nie dałoby wiarygodnej i szczegółowej odpowiedzi na pytanie o rzeczywisty wpływ długu publicznego na wzrost gospodarczy.

Alternatywnym podejściem badawczym jest wtórna analiza polegająca na skwantyfikowanym przeglądzie literatury, którego istotą jest wypracowanie pewnej syntezy na podstawie istniejących badań. Próbę przeprowadzenia metaanalizy dotyczącej badań wpływu długu na wzrost, zgodnie z moją wiedzą, podjęli Moore i Thomas $(2008)^{1}$ oraz Siwińska-Gorzelak $(2015)^{2}$. Obie metaanalizy pokazały, że wpływ zadłużenia publicznego na tempo wzrostu PKB jest różny w zależności od takich czynników jak: metoda agregacji danych, zastosowana metodologia lub próba krajów, na której dane badanie zostało przeprowadzone. Istotne znaczenie miało także tzw. skrzywienie publikacyjne polegające na unikaniu publikowania prac naukowych w przypadku braku wykrycia jakiejś zależności. Według oszacowań zawartych w pracy Siwińskiej-Gorzelak istnieje ujemna i istotna zależność pomiędzy wysokim poziomem długu publicznego a tempem wzrostu PKB. Nale-

\footnotetext{
${ }^{1}$ Przytoczona metaanaliza została opracowana na podstawie 17 publikowanych i niepublikowanych prac badawczych. Opracowania zostały znalezione za pomocą wyszukiwarek JSTOR, EBSCO, ProQuest oraz Google Schoolar przy użyciu słów kluczowych: debt, growth.

${ }^{2}$ Autorka wybrała 21 prac badawczych na podstawie następujących kryteriów: 1. Do wyszukiwania opracowań użyto wyszukiwarki REPEC Ideas i Google Schoolar. 2. Artykuły wyszukiwano za pomocą słów kluczowych public debt, government debt, external debt, growth, development. 3. Wyszukiwanie ograniczono do artykułów zawierających badania empiryczne, opublikowanych po angielsku w recenzowanych pismach oraz seriach opracowań roboczych IMF i NBER. 4. Wykluczono oszacowania, które zawierały wielkość długu podniesioną do kwadratu. 5. Gdy wpływ niskiego zadłużenia na wzrost PKB był różny od wpływu wysokiego zadłużenia, wpływ niskiego zadłużenia został pominięty.
} 
ży jednak zauważyć, że duże zadłużenie oznacza jedynie wartość relacji długu do PKB powyżej pewnego progu, który jest ustalany na różnych poziomach. Wyniki metaanalizy opracowanej przez Moore'a i Thomas (2008) pokazują, że dług może pozytywnie wpływać na wzrost gospodarczy, zwłaszcza jeśli jest finansowany kapitałem zagranicznym. Spośród 17 prac przebadanych przez tych autorów w 11 wykazano pozytywną zależność pomiędzy długiem a wzrostem gospodarczym. Należy jednak zastrzec, że ze względu na rok wydania pominięte zostały badania dotyczące kryzysu zadłużeniowego.

\section{Problemy metodologiczne}

Zasadniczymi problemami metodycznymi, na jakie natrafiają badacze, są niejasności dotyczące endogeniczności oraz przyczynowości długu publicznego względem przyrostu PKB. W badaniach empirycznych często można zaobserwować ujemną korelację pomiędzy tymi zmiennymi, jednak istnieją uzasadnione wątpliwości co do tego, czy wysoki dług publiczny rzeczywiście oddziałuje na niższe tempo wzrostu gospodarczego, lub tego, czy między tymi kategoriami nie występuje odwrotna przyczynowość.

Analizując literaturę dotyczącą tej problematyki (m.in. Ibis, Ranciere 2005; Panizza, Presbitero 2013), można zauważyć, że badacze borykali się głównie z kilkoma problemami. Pierwszym istotnym problemem jest sama konstrukcja wskaźnika długu publicznego. Stosowanie w oszacowaniach ekonometrycznych równoległych obserwacji dla przyrostów PKB oraz wartości stosunków długu do PKB nie może dać jednoznacznej odpowiedzi wskazującej na przyczynowość długu względem wzrostu PKB z powodu konstrukcji zmiennej reprezentującej wielkość długu publicznego (relacja długu publicznego do PKB). Przyrost PKB zwiększa wartość mianownika tej miary, a z drugiej strony obniża jej licznik ze względu na działalność automatycznych stabilizatorów koniunktury lub dyskrecjonalną antycykliczną politykę fiskalną (Reinhart, Rogoff 2011). Dzięki temu zachodzi niejako automatyczna ujemna korelacja w przypadku długu publicznego i przyrostu PKB, jednak nie jest to dowodem na to, że wzrost długu hamuje PKB.

Rozwiązaniem tego problemu może być zastosowanie zmiennej instrumentalnej zastępującej zmienną wyrażającą stosunek długu do PKB, ale wysoce z nią skorelowanej, niebędącej przy tym zależną od dynamiki wzrostu gospodarczego. Do takich zmiennych można zaliczyć wcześniejsze wartości długu publicznego ze względu na wysoką korelację z późniejszymi danymi lub zmienne całkowicie zewnętrzne, jednak mocno skorelowane z wartościami długu. Niektórzy badacze (Panizza, Presbitero 2013; Westphal, Rother 2013) twierdzą jednak, że użycie jako zmiennej instrumentalnej opóźnionej wielkości długu publicznego nie eliminuje, a jedynie zmniejsza problem odwrotnej przyczynowości. 
Po drugie, przyczyną korelacji pomiędzy PKB a długiem publicznym może być również dodatkowy czynnik, który oddziałuje na obie te zmienne, powodując ich endogeniczność. Wydaje się, że ekonomiści nie są zgodni, jeśli chodzi o wyeliminowanie opisanych problemów, jednak - jak się wydaje - można je ograniczyć, wykorzystując w modelach zmienne egzogeniczne skorelowane z bieżącą wartością długu, a nie samą bieżącą wartość stosunku długu publicznego do PKB będącą równoległą obserwacją.

Po trzecie, nie jest jasne, czy wpływ długu publicznego na wzrost gospodarczy ma charakter liniowy. W literaturze przedmiotu można znaleźć prace wskazujące na liniowy, jednoznacznie negatywny wpływ długu (m.in. Modigliani 1961; Saint-Paul 1992), jednak coraz częściej wykorzystuje się podejście zakładające nieliniową zależność pomiędzy tymi zmiennymi (m.in. Hansen 1999; Kumar, Woo 2010; Lind, Mehlum 2010; Checherita-Westphal, Rother 2012; Egert 2012).

Metodą często wykorzystywaną do weryfikowania hipotezy o nieliniowej zależności między wzrostem a długiem jest dodanie do estymowanych zmiennych niezależnych kwadratu długu publicznego. Pozwala to na znalezienie jednej wartości progowej wysokości zadłużenia, po której przekroczeniu dalszy jej przyrost wpływa negatywnie na tempo wzrostu PKB. Inne podejścia zakładają przeprowadzenie przynajmniej kilku regresji dla różnych poziomów długu publicznego. Przykładowo Cordella, Ricci i Ruiz-Arranz (2005), badając kraje HIPC, w skonstruowanym modelu zastosowali kilka regresji w zależności od poziomu długu. Dowiedli, że w krajach tych istnieją dwie wartości progowe, po których przekroczeniu wpływ długu na PKB ulega zmianie. Z kolei Imbs i Ranciere (2005), analizując 87 krajów rozwijających się, starali się zweryfikować hipotezę o nieliniowości wpływu długu publicznego na PKB, nie wyznaczając przy tym wartości progowych, a jedynie wykorzystując metodę „ruchomego okna” (rolling window), polegającą na przeprowadzaniu wielu regresji dla różnych poziomów zadłużenia publicznego.

Wspomniane problemy powodują, że niezmiernie trudno jest ustalić rzeczywisty wpływ długu publicznego na wzrost gospodarczy. Wyniki przeprowadzonych estymacji często zależą od hipotez dotyczących nieliniowości, a także doboru zmiennych reprezentujących wysokość długu publicznego.

\section{Metodologia badania}

W niniejszym opracowaniu postawiono dwie hipotezy. Według pierwszej z nich istnieje zjawisko współwystępowania wysokiego długu publicznego oraz niskiego wzrostu gospodarczego. Według drugiej hipotezy badawczej występuje również przyczynowość między tymi zmiennymi, a od pewnej wysokości dług publiczny zaczyna negatywnie wpływać na tempo wzrostu gospodarczego. Zakłada się 
również, że punkt zwrotny, po przekroczeniu którego dług zaczyna negatywnie wpływać na wzrost gospodarczy, jest na niższym poziomie niż 85\%. Proponowana wartość graniczna progu nawiązuje do badań m.in. Reinhart i Rogoffa (2010) oraz Westphal i Rothera (2013), w których dla państw rozwiniętych wartość graniczna stosunku zadłużenia do PKB wynosiła $85-100 \%$. Do zweryfikowania pierwszej hipotezy badawczej zakładającej współwystępowanie opisywanych zjawisk wykorzystano analizę statystyk opisowych zawierających: średnią, medianę, minimum oraz maksimum. Analizę średnich dodatkowo podzielono zależnie od sposobu agregacji danych.

Pierwszy sposób agregacji polegał na wyliczeniu średnich wzrostu gospodarczego oraz długu publicznego dla poszczególnych państw w badanym okresie. Następnie na podstawie tych danych oszacowano równania regresji, w przypadku których zmienną zależną było tempo wzrostu gospodarczego, a zmienną niezależną - dług publiczny. Kolejnym krokiem była agregacja nie ze względu na poszczególne kraje, lecz w podziale na obserwacje mieszczące się w wartościach granicznych stosunku długu publicznego do PKB. Ustalono trzy progi: do $30 \%, 31-60 \%$ oraz powyżej $60 \%$. Zakres przyjętych przedziałów wynikał z praktyk stosowanych przez innych autorów - m.in. Reinhart i Rogoffa (2010) - oraz liczby obserwacji obejmujących skrajne wielkości zadłużenia. W literaturze można spotkać estymacje dla wielkości progowych nawet na poziomie powyżej $90 \%$, jednak tylko dwie z zebranych obserwacji przekroczyły tę wartość, więc zaniechano prezentacji statystyk w tym przypadkach. Dla tak przyjętych przedziałów zaprezentowano również statystyki median, minimów oraz maksimów.

Uśrednione wartości obserwacji pokazują, że w okresie 1996-2017 zdecydowanie najniższy stosunek długu publicznego do PKB można było zaobserwować w Estonii - 6,7\% (zob. tabela 1), a najbardziej zadłużonym państwem okazały się Węgry ze średnią relacją długu do PKB na poziomie 67,8\%. Drugim najbardziej zadłużonym krajem była Chorwacja, jednak należy zauważyć, że stosunek długu do PKB w przypadku tego kraju był o 16,4 pp. mniejszy niż w przypadku Węgier. Na wykresach 1 i 2 zaprezentowano równania regresji z trendem liniowym. Jako zmienne objaśniane zastosowano w pierwszym równaniu średnioroczny procentowy wzrost $\mathrm{PKB}$, a w drugim - skumulowany roczny wskaźnik wzrostu PKB (ang. Compound Annual Growth Rate). Zmienną objaśniającą jest stosunek długu publicznego do PKB. Otrzymane statystyki $\mathrm{R}^{2}$ na poziomie $0,292-0,339$ świadczą o umiarkowanej ujemnej zależności wskaźników przyrostu PKB per capita względem średniej relacji długu publicznego do PKB. Kraje takie jak Polska, Słowacja, Litwa, Łotwa oraz Bułgaria osiągnęły wyższy średni wzrost gospodarczy niż wynika to z zaprezentowanych linii trendu. Wyliczone równania oraz zaprezentowane trendy ze względu na niewielką liczbę obserwacji, a także równoległe szeregi czasowe są jednak poglądowe. 
Tabela 1. Statystyki dotyczące relacji długu do PKB oraz średniego przyrostu PKB per capita dla wybranych krajów Europy Środkowo-Wschodniej w latach 1996-2017

\begin{tabular}{|c|c|c|c|c|c|c|c|c|c|c|c|}
\hline & \multicolumn{11}{|c|}{ Kraj } \\
\hline & 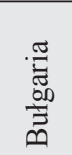 & $\begin{array}{l}\frac{\pi}{0} \\
\frac{\pi}{2} \\
0 \\
0 \\
0\end{array}$ & $\begin{array}{l}\text { త্ } \\
\stackrel{N}{N} \\
\text { U }\end{array}$ & . & $\sum_{=}^{\pi}$ & $\sum_{0}^{\pi}$ & $\frac{\pi}{\frac{\pi}{0}}$ & 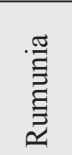 & $\begin{array}{l}\frac{\pi}{0} \\
\frac{\pi}{2} \\
\frac{3}{\omega}\end{array}$ & $\begin{array}{l}\cdot \frac{\pi}{3} \\
\frac{0}{0} \\
\frac{3}{\pi}\end{array}$ & $\vec{b}_{3}^{\infty}$ \\
\hline $\begin{array}{l}\text { Średni udział długu pu- } \\
\text { blicznego w PKB (\%) }\end{array}$ & 41,5 & 51,4 & 29,1 & 6,7 & 26,5 & 23,7 & 46,6 & 24,5 & 42,2 & 40,0 & 67,8 \\
\hline $\begin{array}{l}\text { Średnioroczny procentowy } \\
\text { wzrost PKB }\end{array}$ & 3,7 & 2,8 & 2,5 & 4,6 & 5,5 & 5,3 & 4,1 & 3,8 & 3,9 & 2,5 & 2,6 \\
\hline $\begin{array}{l}\text { Skumulowany roczny } \\
\text { wskaźnik wzrostu PKB } \\
\text { (CAGR) }\end{array}$ & 3,8 & 2,4 & 2,3 & 4,3 & 5,3 & 5,2 & 4,0 & 3,7 & 3,7 & 2,4 & 2,7 \\
\hline
\end{tabular}

Źródło: opracowanie własne na podstawie danych Banku Światowego oraz Eurostatu.

Wykres 1. Równanie regresji dla średniorocznego przyrostu PKB per capita oraz średniej relacji długu do PKB dla wybranych państw Europy Środkowo-Wschodniej w latach 1996-2017

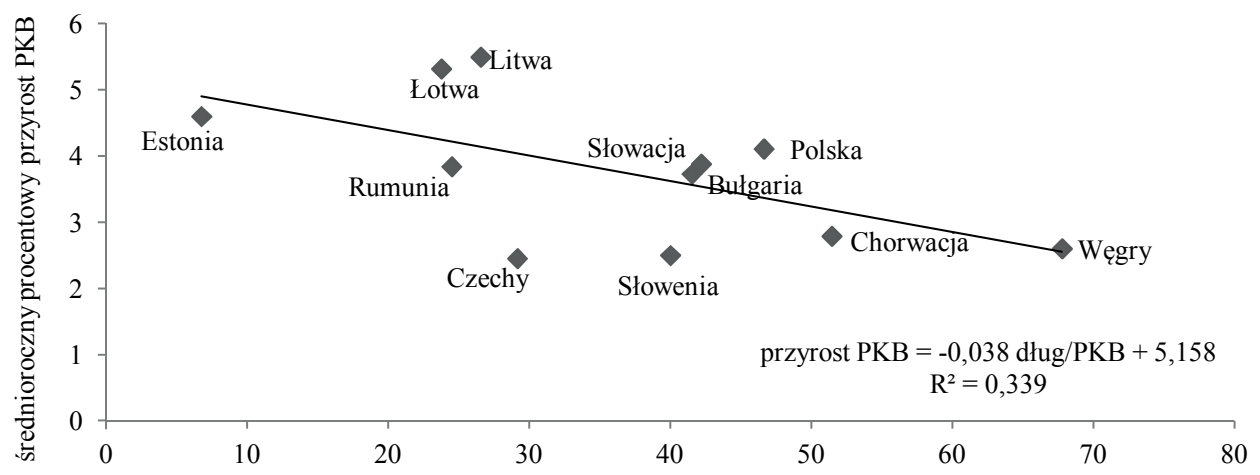

Źródło: opracowanie własne na podstawie danych Banku Światowego oraz Eurostatu.

Wykres 2. Równanie regresji dla skumul. rocznego wskaźnika wzrostu (CAGR) PKB per capita i średniej relacji długu do PKB dla wybranych państw Europy Środk.-Wsch. w latach 1996-2017

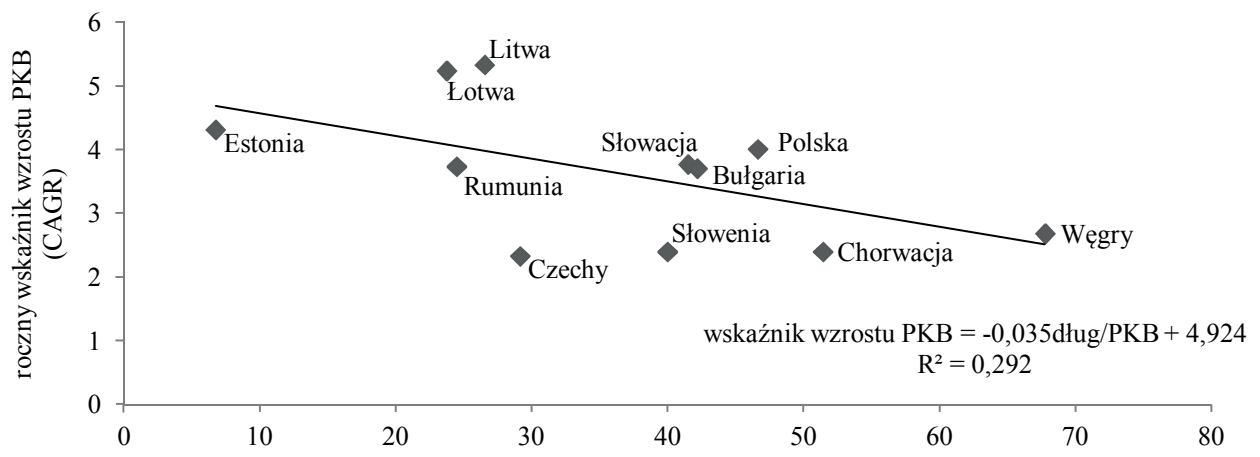

Źródło: opracowanie własne na podstawie danych Banku Światowego oraz Eurostatu. 
Próba danych, w której zagregowano obserwacje ze względu na poszczególne przedziały długu publicznego w PKB, liczyła 242 przypadki (11 krajów badanych w odniesieniu do okresu 1996-2017). W przypadku 105 obserwacji odnotowano relację długu publicznego do PKB na poziomie do 30\% włącznie. 104 obserwacje charakteryzowały się stosunkiem długu do PKB w przedziale między $31 \%$ a $60 \%$, a w przypadku 33 obserwacji stosunek ten przekroczył 60\%. Statystyki dotyczące średniej oraz mediany wskazują, że wraz z przekraczaniem kolejnych progowych wartości długu przeciętny wzrost gospodarczy obniża się. Analizując wyliczone średnie wartości, można zaobserwować, że wraz ze zwiększaniem przedziału relacji długu do PKB do 31-60\% średni wzrost gospodarczy obniża się o 1,4 pp. W przypadku najwyższego progu zadłużenia, przekraczającego $60 \%$, średnie tempo wzrostu obniżyło się o kolejne 1,4 pp. Maksymalne wartości odnotowanych przyrostów PKB także były większe wtedy, gdy zadłużenie było mniejsze. Jednak warto zwrócić uwagę na to, że obserwacje cechujące się największym załamaniem wzrostu gospodarczego zostały odnotowane w przypadku mniejszego zadłużenia. Na Litwie, pomimo niewielkiego zadłużenia publicznego, w 2009 r. wystąpił największy spadek tempa wzrostu gospodarczego spośród wszystkich analizowanych państw (-14,8\%), a w grupie krajów relatywnie najbardziej zadłużonych największym spadkiem tempa PKB charakteryzowały się Węgry $(-6,4 \%)$. Oznacza to, że w przypadku obserwacji o wyższym współczynniku zadłużenia można się było spodziewać mniejszych wahań tempa wzrostu PKB per capita.

Wykres 3. Statystyki opisowe dla wzrostu PKB w krajach Europy Środkowo-Wschodniej w zależności od wysokości długu publicznego w relacji do PKB per capita

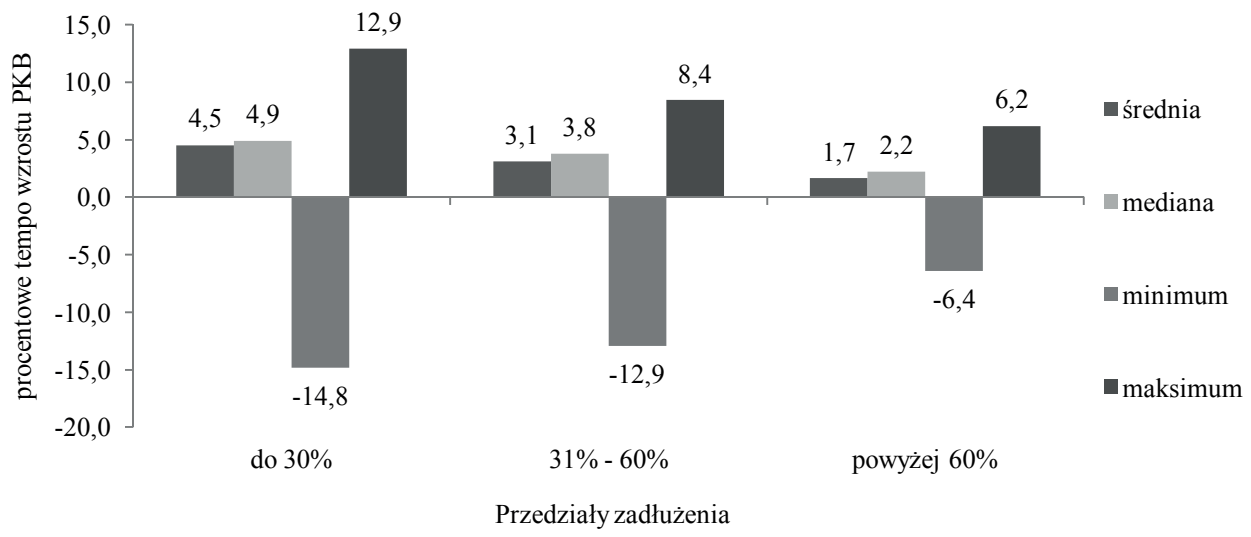

Źródło: opracowanie własne na podstawie danych Banku Światowego oraz Eurostatu.

Zgodnie z zaprezentowaną analizą statystyk opisowych oraz przytoczonym wcześniej przeglądem literatury należy domniemywać, że wielkość długu przynajmniej w pewnym zakresie może wywierać wpływ na tempo wzrostu gospodarczego. Relacja pomiędzy opisywanymi wartościami często nie jest 
liniowa - dopiero po przekroczeniu pewnej krytycznej wartości dług publiczny zaczyna negatywnie wpływać na wzrost gospodarczy. W celu weryfikacji tej hipotezy skonstruowano cztery modele ekonometryczne dla danych panelowych; są to: klasyczny model najmniejszych kwadratów, model z efektami ustalonymi (fixed effects), systemowa uogólniona metoda momentów (Blundell, Bond 1998) oraz uogólniona metoda momentów pierwszych różnic (Arellano, Bond 1991). Do badania wykorzystano dane roczne dotyczące 11 krajów Europy Środkowo-Wschodniej ${ }^{3}$ z lat 1996-2017. Dane pochodzą z baz statystycznych Banku Światowego (World Development Indicators) oraz Eurostatu 4 . W przeprowadzonych analizach jako zmienną zależną wykorzystano tempo wzrostu PKB per capita. Aby zweryfikować hipotezę o nieliniowej zależności pomiędzy wzrostem gospodarczym a długiem publicznym, posłużono się zmiennymi niezależnymi, obejmującymi m.in. dane dla udziału zadłużenia publicznego w PKB oraz kwadratu tej wielkości. Jako pozostałe zmienne kontrolne, mające za zadanie zmniejszyć potencjalne obciążenie zmiennych zawierających dane o zadłużeniu, włączono:

1. udział inwestycji w PKB (inwestycje);

2. udział wydatków publicznych w PKB (wydatki publiczne);

3. procentowy rzeczywisty przyrost ludności danego kraju (przyrost populacji);

4. wskaźnik inflacji CPI (inflacja);

5. $\mathrm{PKB}$ per capita $\mathrm{w}$ cenach stałych z $2010 \mathrm{r}$. z zachowaniem parytetu siły nabywczej (PKB per capita);

6. udział pracowników z wykształceniem wyższym wśród ogółu siły roboczej (wykształceni pracownicy);

7. udział osób w wieku 0-14 oraz 64 i więcej wśród ogółu ludności (obciążenie demograficzne);

8. sumę udziałów eksportu i importu w PKB opisującą otwartość gospodarki (handel);

9. deficyt budżetowy jako odsetek PKB (deficyt);

10. opóźnioną wartość przyrostu PKB per capita (przyrost PKB per capita $(\mathrm{t}-1))$.

Dobór zmiennych kontrolnych w znacznej mierze wynikał z analizy porównawczej przeprowadzonej na potrzeby analogicznych badań nad wpływem zadłużenia publicznego na przyrost PKB (por. np. Siwińska-Gorzelak, Mencinger i in., Westphal $\mathrm{i}$ in.).

Zmienna ukazująca wielkość inwestycji została włączona dlatego, że jest ona zasadniczą determinantą tworzenia nowego kapitału produkcyjnego przy-

\footnotetext{
${ }^{3}$ Badanie obejmowało następujące kraje: Bułgarię, Chorwację, Czechy, Estonię, Litwę, Łotwę, Polskę, Rumunię, Słowację, Słowenię oraz Węgry. Z powodu braku danych z analizy wykluczono: Białoruś, Ukrainę, Bośnię i Hercegowinę, Serbię, Czarnogórę, Macedonię oraz Albanię.

${ }^{4}$ Gdy brakowało pojedynczych wartości, przypisywano wartość z roku następnego. Braki danych nie przekraczały jednak $10 \%$ całego zbioru.
} 
czyniającego się do zwiększania potencjalnego poziomu PKB. Kapitał to zmienna standardowo umieszczana zarówno w neoklasycznych, jak i endogenicznych modelach wzrostu gospodarczego, m.in. Solow (1956), Diamond (1965), Romer (1986), Lucas (1988), Rebelo (1991) Mankiw - Romer - Weil (1992) oraz Aghion-Howitt (1992).

Wielkość wydatków publicznych może mieć również wpływ na tempo wzrostu PKB, co odzwierciedla model Barro (1990), gdzie do argumentów funkcji produkcji dołączono produktywne wydatki publiczne. W późniejszych pracach, m.in. metaanalizie Nijkamp i Poot (2004), Magazzino (2011), Afonso i Furceri (2010) oraz Lamartina i Zaghini (2011) potwierdzono, że większość z grup wydatków mieszczących się w klasyfikacji COFOG (ang. Classification of the Functions of Government) ma wpływ na wzrost gospodarczy.

Rzeczywisty przyrost ludności może dwojako wpływać na przyrost PKB per capita. Z jednej strony może doprowadzić do nadmiernej eksploatacji zasobów naturalnych oraz przewyższać wzrost produkcji żywności (zob. np. Malthus 1798; Coale i Hoover 1958; Meadows i in. 1972; Barney 1980; Yamaguchi 2001). Z drugiej strony podkreśla się pozytywny wpływ na powstawanie nowych technologii oraz występowanie efektu skali związanego z przyrostem zatrudnionych (zob. np. Kuznets 1967; Romer 1990; Kernel 1993; Mankiw 2010).

Wielkość inflacji włączono, gdyż jest to zmienna wywołująca szereg skutków ekonomicznych. Wysoka inflacja powoduje m.in. wzrost niepewności, wzrost kosztów obsługi działalności gospodarczej, zniekształcenie informacyjnej funkcji cen, niepożądaną redystrybucję dochodów i tzw. ucieczkę od pieniądza. Wymienione skutki pośrednio wpływają na wzrost gospodarczy oraz stabilność ekonomiczną (zob. np. Fisher 1993; Barro 1995; Bruno, Easterly 1998; Khan, Senhadji 2001; Kramer i in. 2013).

Poziom PKB per capita został umieszczony ze względu na domniemanie występowania hipotezy konwergencji. Teoria konwergencji wynika z założeń neoklasycznych oraz nowych teorii wzrostu gospodarczego (m.in. Solow 1956; Grossman, Helpman 1991; Mankiw, Romer, Weil 1992) zakładających malejącą produktywność kapitału, a w konsekwencji - szybszy wzrost gospodarczy w krajach biedniejszych. W przypadku tej hipotezy można przypuszczać, że kraje o wyższym PKB per capita będą odnotowywać mniejszy jego przyrost.

Udział pracowników z wyższym wykształceniem jest zmienną reprezentującą inwestycje w kapitał ludzki - często wykorzystywany w modelach wzrostu gospodarczego obok kapitału fizycznego. Kapitał ludzki jako zmienna występuje w dwusektorowych modelach wzrostu, m.in. Mankiwa, Romera, Weila (1992), Lucasa (1988), Romera (1986) i Rebelo (1991).

Obciążenie demograficzne przyczynia się do zmniejszenia liczby osób aktywnych zawodowo, a w konsekwencji - do zmniejszenia produkcji. Liczba osób aktywnych zawodowo stanowi jeden z argumentów funkcji produkcji wyrażonej w tradycyjnych oraz endogenicznych koncepcjach wzrostu gospodarczego (m.in. 
Solow 1956; Grossman, Helpman 1991; Mankiw, Romer, Weil 1992). Zwiększenie się liczby osób w wieku nieprodukcyjnym w stosunku do liczby osób w wieku produkcyjnym zazwyczaj obniża wielkość zasobu pracy w przeliczeniu na mieszkańca danego kraju, a więc również PKB per capita. Pozytywny wpływ rosnącego udziału siły roboczej w całej populacji na wzrost gospodarczy potwierdzają badania m.in. Blooma i Williamsona (1998), Blooma, Canninga i Malaney (2000) oraz Kelley'ego i Schmidta (2005).

Otwartość gospodarki mierzona sumą udziałów eksportu i importu w PKB może pozytywnie lub negatywnie wpływać na tempo PKB, jednak często występuje jako punkt odniesienia w modelowaniu wzrostu gospodarczego. Pozytywny wpływ otwartości handlu na gospodarkę jest uzasadniony w teorii przewag komparatywnych Torrensa (1808), spopularyzowanej przez Ricardo (1817), zgodnie z którą gospodarki poszczególnych krajów zwiększają potencjalną produkcję dzięki wprowadzeniu specjalizacji i braku barier celnych. Nowsze teorie wymiany handlowej, zaprezentowane m.in. przez Helpmana i Krugmana (1985) oraz Romera (1986), podkreślają zalety zwiększonej wymiany handlowej związane z przyciąganiem inwestycji zagranicznych, pozytywnym oddziaływaniem na przedsiębiorczość oraz przepływem nowych technologii. Jednak według niektórych autorów liberalizacja handlu może wpływać na wzrost gospodarczy tylko w przypadku pewnej grupy krajów rozwiniętych, negatywnie oddziałując na wzrost gospodarczy w krajach rozwijających się (m.in. Dollar 1992; Sachs, Warner 1995; Edwards 1998; Frankel, Romer 1999; Yanikkaya 2003; Lee 2005).

Kierunek wpływu deficytu budżetowego na tempo PKB nie jest jednoznacznie określony i często zależy od różnych dodatkowych czynników, jednak analizy niektórych naukowców pokazują, że zmienna ta ma istotny wpływ na wzrost. Fisher (1993) podkreśla negatywne oddziaływanie deficytu budżetowego na akumulację kapitału i wydajności czynników produkcji, co przekłada się na spadek tempa wzrostu PKB. Kneller, Gemmell i Bleaney (1999) twierdzą, że jeśli deficyt budżetowy wystąpi na skutek cięć w podatkach zniekształcających alokację zasobów bądź wzrostu produktywnych wydatków publicznych to jego oddziaływanie na wzrost gospodarczy będzie pozytywne. Według badań Adam i Bevan (2005) dotyczących 45 krajów rozwiniętych redukcja deficytu budżetowego do maksymalnej wielkości $1,5 \%$ PKB pozytywnie wpływa na tempo wzrostu. Wartość produktywności wydatków na inwestycje poczynione dzięki pożyczce państwa podkreślają także m.in. Gupta i Baldacci (2005), Bose, Haque i Osborn (2007) oraz Brender i Drazen (2008).

Po wstępnej estymacji zaprezentowanego modelu odrzucone zostały zmienne kontrolne o niskim poziomie istotności, który dla statystyki $p$ przekroczył $10 \%$. Okazało się, że we wszystkich czterech modelach odnotowano ten sam zestaw nieistotnych parametrów. Wśród zmiennych kontrolnych ujętych w modelu ostatecznie znalazły się: udział inwestycji w PKB (inwestycje), udział wydatków publicznych w PKB (wydatki publiczne) oraz procentowy rzeczywisty przyrost ludności 
danego kraju (przyrost populacji). W celu uniknięcia zaburzenia estymacji modelów wyeliminowano obserwacje odstające, tj. wartości liczbowe zmiennych dla krajów bałtyckich (Litwa, Łotwa i Estonia) w latach 2008-2009. Wówczas te państwa odnotowały wyjątkowo wysoki spadek produkcji, będący efektem wybuchu kryzysu finansowego. Podstawowy model przyjął ostatecznie następującą postać:

$Y_{i, t}=\alpha_{0}+\beta_{1} D_{i, t-1}+\beta_{2} K D_{i, t-1}+\beta_{3} X_{i, t}+\left(\alpha_{1}+\varepsilon_{i, t}\right)$

gdzie:

$Y_{i, t}$ - poziom przyrostu PKB per capita $\mathrm{w} i$-tym regionie w okresie $t$

$\alpha_{0,} \beta_{1,} \beta_{2} \beta_{3}$ - parametry strukturalne

$D_{i, t}$ - udział długu publicznego w PKB w $i$-tym regionie w okresie $t$

$K D_{i, t}$ - kwadrat udziału długu publicznego w PKB w $i$-tym regionie w okresie $t$

$X_{i, t}$ - wektor zmiennych kontrolnych w $i$-tym regionie w okresie $t$

$\alpha_{1}$ - efekty grupowe

$\varepsilon_{i, t}-$ składnik losowy

W celu eliminacji problemu odwrotnej przyczynowości oraz automatycznej ujemnej korelacji w modelach zastosowano opóźnione o jeden okres zmienne objaśniające: dlug publiczny oraz kwadrat dtugu publicznego. Aby przeprowadzić oszacowania dynamiczne modeli panelowych UMM systemowej oraz UMM pierwszych różnic, do zmiennych niezależnych dodano opóźnioną o jeden okres zmienną zależną - przyrost PKB per capita - w celu polepszenia właściwości modeli. Opóźnionej zmiennej zależnej nie dodano do statycznych modeli KMNK oraz modelu z efektami stałymi z powodu potencjalnej niezgodności i obciążenia estymatorów. Do weryfikacji jakości modeli KMNK oraz modelu z efektami stałymi użyto statystyki $\mathrm{R}^{2}$, a jakość modeli bazujących na uogólnionej metodzie momentów oceniono na podstawie testu autokorelacji Arellando - Bonada (AR 1, AR 2). Wyniki testu zawarte w tabeli 2 dla modeli metody momentów świadczą o tym, że warunki momentów wykorzystane w procesie estymacji są poprawne w obu przypadkach. Wartości testu AR (1) oraz AR (2) pokazują, że w omawianych modelach występuje autokorelacja pierwszego rzędu, a brakuje autokorelacji drugiego rzędu. Instrumenty użyte podczas estymacji są zatem właściwe.

\section{Wyniki estymacji modeli panelowych}

Analizując wyniki estymacji zaprezentowanych modeli (zob. tabela 2), można potwierdzić hipotezę o nieliniowej zależności pomiędzy wzrostem gospodarczym a wielkością długu publicznego. Dodatni współczynnik zmiennej $d t u g(t-l)$ oraz ujemny zmiennej kwadrat dtugu (t-l) świadczy o tym, że zależność pomiędzy długiem a wzrostem ma kształt odwróconej litery „U”. Z przedstawionych 
wyliczeń wynika, że wielkość graniczna relacji długu publicznego do PKB, po której należy spodziewać się obniżenia tempa wzrostu gospodarczego, waha się w przedziale $67,3-77,0 \%$. Świadczą o tym wartości ekstremów funkcji kwadratowych ze zmienną zależną wzrost gospodarczy oraz zmiennymi niezależnymi dlug (t-1) i kwadrat dlugu (t-1). Oznacza to, że wskaźnik długu publicznego w 8 z 11 analizowanych państw (z wyjątkiem Chorwacji, Słowenii oraz Węgier) nie przekroczył najniższej wielkości granicznej (67,3\%) w 2017 r. W trzech krajach wartości zadłużenia przekraczały progi wyliczone za pomocą modelu KMNK, modelu z efektami stałymi oraz UMM systemowej na poziomach $63,7 \%$, $70,1 \%$ oraz $70,9 \%$. Jedynie w Chorwacji został przekroczony również najwyższy próg zadłużenia wyliczony za pomocą modelu UMM pierwszych różnic $(77,0 \%)$.

Tabela 2. Wyniki estymacji parametrów równania bezpiecznego poziomu zadłużenia

\begin{tabular}{|c|c|c|c|c|}
\hline \multirow[b]{2}{*}{ Zmienna } & \multicolumn{4}{|c|}{ Model } \\
\hline & KMNK & $\begin{array}{l}\text { Model z efekta- } \\
\text { mi stałymi }\end{array}$ & $\begin{array}{c}\text { UMM } \\
\text { systemowa }\end{array}$ & $\begin{array}{l}\text { UMM pierw- } \\
\text { szych różnic }\end{array}$ \\
\hline \multirow{2}{*}{ Dług (t-1) } & $0,0738 * *$ & $0,0810 * *$ & $0,1078 * *$ & $0,1985^{* * *}$ \\
\hline & $(0,0326)$ & $(0,0382)$ & $(0,0464)$ & $(0,0433)$ \\
\hline \multirow{2}{*}{ Kwadrat długu (t-1) } & $-0,0005^{*}$ & $-0,0006^{*}$ & $-0,0008^{* *}$ & $-0,0013 * * *$ \\
\hline & $(0,0003)$ & $(0,0003)$ & $(0,0003)$ & $(0,0003)$ \\
\hline \multirow{2}{*}{ Inwestycje } & $0,2908 * * *$ & $0,3615 * * *$ & $0,2860 * * *$ & $0,3776^{* * *}$ \\
\hline & $(0,0575)$ & $(0,0646)$ & $(0,0641)$ & $(0,0715)$ \\
\hline \multirow{2}{*}{ Wydatki publiczne } & $-0,2425 * *$ & $-0,3906 * * *$ & $-0,2745^{* * *}$ & $-0,4519 * * *$ \\
\hline & $(0,0533)$ & $(0,0721)$ & $(0,0743)$ & $(0,1191)$ \\
\hline \multirow{2}{*}{ Przyrost populacji } & $-0,1895^{* * *}$ & $-0,1876^{* * *}$ & $-0,1736 * * *$ & $-0,1775^{* * *}$ \\
\hline & $(0,0402)$ & $(0,0505)$ & $(0,0282)$ & $(0,0245)$ \\
\hline \multirow{2}{*}{$\begin{array}{l}\text { Przyrost } \mathrm{PKB} \\
\text { per capita }(\mathrm{t}-1)\end{array}$} & - & - & $0,1483^{*}$ & 0,0666 \\
\hline & - & - & $(0,0816)$ & $(0,0820)$ \\
\hline Punkt zwrotny & 67,30 & 70,10 & 70,9 & 77,0 \\
\hline Liczba obserwacji & 222,00 & 222,00 & 222,00 & 211,00 \\
\hline Współczynnik $\mathrm{R}^{2}$ & 0,33 & 0,44 & - & - \\
\hline Test AR1 & - & - & $-2,3356$ & $-2,3362$ \\
\hline Wartość $p$ dla testu AR1 & - & - & 0,0195 & 0,0195 \\
\hline Test AR2 & - & - & $-0,0336$ & $-0,2471$ \\
\hline Wartość $p$ dla testu AR2 & - & - & 0,9732 & 0,8048 \\
\hline
\end{tabular}

Symbole ***,*** świadczą o istotności parametru odpowiednio na poziomach: 1\%, 5\% oraz $10 \%$; w nawiasach podano błędy standardowe.

Źródło: opracowanie własne przy użyciu programu GRETL na podstawie danych Eurostatu oraz Banku Światowego (World Development Indicators). 
Porównując otrzymane wyniki z wcześniej omówionymi badaniami, należy zwrócić uwagę na kilka kwestii. Jedna z hipotez niniejszej analizy zakłada, że oddziaływanie długu na wzrost jest nieliniowe, co zostało ujęte w specyfikacji modeli ekonometrycznych. Wobec tego zakres porównań będzie dotyczył autorów, którzy w swoich pracach uwzględnili hipotezę nieliniowego oddziaływania. Część analiz, w których dowiedziono występowania nieliniowej relacji między długiem a wzrostem, dotyczy wyszczególnionej grupy krajów rozwijających się, w tym należących do grupy badawczej niniejszego opracowania. Prezentowane wyniki dotyczą nowych krajów członkowskich UE z Europy Środkowo-Wschodniej, wobec czego większy nacisk położono na odniesienie się do studiów uwzględniających podobną grupę badawczą.

W opracowaniach, w których nie rozróżniono grupy badawczej (zob. tabela 3), można zauważyć, że w przypadku trzech spośród pięciu prezentowanych badań odnotowano niższą wartość bezpiecznego zadłużenia (Afonso, Jalles 2013; Egert 2015; Chen, Yao, Hu, Lin 2016). Najbardziej obszerne pod względem liczby krajów opracowanie, Afonso i Jallesa, wskazuje na próg bezpiecznego zadłużenia o wartości 59\%. Wyniki badań Bilana i Inhatowa (2015) oraz Canera i in. (2010), w których wyliczono większe granice zadłużenia, różnią się od siebie o 16,9 pp., jednak należy zauważyć znaczącą różnicę w doborze wielkości grupy badawczej.

Wartości krytyczne bezpiecznego poziomu zadłużenia dla krajów rozwiniętych wyliczone $w$ niniejszym opracowaniu są z kolei zazwyczaj niższe niż przytoczone w analizach innych autorów. Jedynie w badaniu Baum i in. oraz Puig i Rivery występują modele, w ktorych dowiedziono niższych bezpiecznych poziomów długu. W analizie Baum i in. niższa graniczna wartość zadłużenia występuje dla szeregu czasowego kończącego się przed wybuchem kryzysu gospodarczego. Po uwzględnieniu okresu kryzysowego wartość progowa w zależności od modelu wzrasta przynajmniej o 5,3 pp., często przewyższając wartość graniczną wyliczoną w niniejszej analizie. W pracy Puig i Rivery wartości bezpiecznego poziomu długu poniżej 77\% wyliczono dla Holandii i Hiszpanii - odpowiednio: 56\% i 53\%. W przypadku pozostałych krajów objętych badaniem były one wyższe.

W zdecydowanej większości analiz, w których uwzględniono grupę krajów rozwijających się, oszacowane wartości progowe były niższe i wynosiły $42,3-$ $60 \%$. Jedynie w badaniu Karadama (2018) wyliczono próg granicznego zadłużenia na poziomie $88,2 \%$. Warto jednak zauważyć, że w opracowaniu tego autora grupa badawcza jest zdecydowanie najobszerniejsza.

Szczególnie interesującymi studiami w kontekście analizy porównawczej są opracowania Mencingera $i$ in. (2014) oraz Bilan (2015), ponieważ dotyczą bardzo podobnej lub identycznej grupy krajów ${ }^{5}$ oraz uwzględniają następstwa kryzysu gospodarczego. W badaniu Mencingera i in. próg bezpiecznego poziomu

\footnotetext{
${ }^{5}$ Badanie Mencingera $\mathrm{i}$ in. obejmuje oddzielnie 10 krajów UE, które dołączyły do wspólnoty po rozszerzeniu w 2005 r. W opracowaniu Bilan grupa badawcza jest identyczna, jednak w niektórych przypadkach wyłączane z oszacowań są dwa kraje - Bułgaria i Rumunia.
} 
zadłużenia został oszacowany za pomocą modelu uogólnionej metody momentów ze zmiennymi instrumentalnymi (ang. GMM IV) i wyniósł 53,5\%. Niższa wartość graniczna może wynikać z nieco odmiennej metody badania, krótszej próby czasowej oraz częściowo innych zmiennych kontrolnych. W analizie Mencingera et al. pominięto zmienną obrazującą przyrost populacji. Pewien wpływ może mieć też uwzględnienie w próbie badawczej Cypru i Malty oraz nieuwzględnienie Bułgarii, Chorwacji i Rumunii. Oszacowania w badaniu Bilan (2015) dotyczą identycznej grupy krajów, jednak można zauważyć różnice w okresie badawczym oraz specyfikacji modelów ekonometrycznych. Zmienne kontrolne obejmują dodatkowo: logarytm przyrostu PKB per capita, otwartość gospodarki ${ }^{6}$, deficyt budżetowy, wskaźnik praw politycznych i wolności obywatelskich (ang. Freedom in the World) oraz w jednym przypadku zmienną obrazującą wystąpienie kryzysu gospodarczego.

Tabela 3. Wybrane badania, w których zdiagnozowano nieliniowy charakter relacji między długiem publicznym a wzrostem gospodarczym

\begin{tabular}{|c|c|c|c|c|c|c|}
\hline \multirow{2}{*}{$\begin{array}{l}\text { Autorzy } \\
\text { badania }\end{array}$} & \multirow{2}{*}{$\begin{array}{l}\text { Metoda } \\
\text { badawcza }\end{array}$} & \multirow{2}{*}{$\begin{array}{l}\text { Przedział } \\
\text { czasowy }\end{array}$} & \multirow{2}{*}{$\begin{array}{l}\text { Liczba krajów } \\
\text { ujęta w badaniu } \\
\text { oraz podział grupy } \\
\text { badawczej }\end{array}$} & \multicolumn{3}{|c|}{$\begin{array}{c}\text { Graniczne wartości } \\
\text { bezpiecznego zadłużenia } \\
\text { (stosunek długu publicznego } \\
\text { do PKB) }(w \%)\end{array}$} \\
\hline & & & & $\begin{array}{l}\text { brak } \\
\text { podzia- } \\
\text { łu na gr. } \\
\text { badaw. }\end{array}$ & $\begin{array}{l}\text { kraje } \\
\text { rozwi- } \\
\text { jające } \\
\text { się }\end{array}$ & $\begin{array}{l}\text { kraje } \\
\text { rozwi- } \\
\text { nięte }\end{array}$ \\
\hline $\begin{array}{l}\text { Afonso } \\
\text { i Jalles } \\
\text { (2013) }\end{array}$ & $\begin{array}{l}\text { modele metody } \\
\text { najmn. kwadra- } \\
\text { tów (OLS, IV- } \\
\text {-GLS), modele z } \\
\text { efektami stałymi } \\
\text { (FE) oraz modele } \\
\text { uogólnionej me- } \\
\text { tody momentów } \\
\text { (GMM - SYS) }\end{array}$ & 1970-2008 & $\begin{array}{l}155 \text { krajów, brak } \\
\text { podziału grupy } \\
\text { badawczej }\end{array}$ & 59,00 & - & - \\
\hline $\begin{array}{l}\text { Baum, } \\
\text { Checherita- } \\
\text {-Westphal, } \\
\text { Rother } \\
(2013)\end{array}$ & $\begin{array}{l}\text { dynamiczne mo- } \\
\text { dele panelowe, } \\
\text { podwójna metoda } \\
\text { najmn. kwadra- } \\
\text { tów (IV 2SLS) }\end{array}$ & $1990-2010$ & $\begin{array}{l}12 \text { rozwiniętych } \\
\text { krajów strefy euro }\end{array}$ & - & - & $\begin{array}{l}66,4- \\
95,6\end{array}$ \\
\hline $\begin{array}{l}\text { Bilan } \\
(2015)\end{array}$ & $\begin{array}{l}\text { modele metody } \\
\text { najmn. kwadra- } \\
\text { tów (OLS) }\end{array}$ & 1994-2013 & $\begin{array}{l}11 \text { nowych krajów } \\
\text { członkowskich UE } \\
\text { z Europy Srodk.- } \\
\text {-Wschodniej }\end{array}$ & - & $\begin{array}{l}42,3- \\
55,3\end{array}$ & - \\
\hline $\begin{array}{l}\text { Bilan } \\
\text { i Inhatow } \\
\text { (2015) }\end{array}$ & $\begin{array}{l}\text { modele metody } \\
\text { najmn. kwadra- } \\
\text { tów (OLS) }\end{array}$ & 1990-2011 & $\begin{array}{l}22 \text { rozwinięte kraje } \\
\text { UE oraz } 11 \text { krajów } \\
\text { rozwijających się } \\
\text { należących do UE } \\
\text { oraz kandydujących }\end{array}$ & 93,90 & 44,70 & 98,60 \\
\hline
\end{tabular}

${ }^{6}$ Zmienna wyrażająca sumę udziałów eksportu i importu w stosunku do PKB. 


\begin{tabular}{|c|c|c|c|c|c|c|}
\hline $\begin{array}{l}\text { Caner, } \\
\text { Grennes, } \\
\text { Koehler- } \\
\text {-Geib } \\
(2010) \\
\end{array}$ & $\begin{array}{l}\text { modele metody } \\
\text { najmn. kwadra- } \\
\text { tów (OLS) }\end{array}$ & 1980-2008 & $\begin{array}{l}101 \text { krajów, brak } \\
\text { podziału grupy } \\
\text { badawczej }\end{array}$ & 77,0 & - & - \\
\hline $\begin{array}{l}\text { Cecchetti, } \\
\text { Mohanty, } \\
\text { Zampolli } \\
\text { (2011) }\end{array}$ & $\begin{array}{l}\text { modele z efektami } \\
\text { stałymi (FE) oraz } \\
\text { modele uogólnio- } \\
\text { nej metody mo- } \\
\text { mentów (GMM) }\end{array}$ & 1980-2010 & $\begin{array}{l}18 \text { rozwiniętych } \\
\text { krajów OECD }\end{array}$ & - & - & $84-96$ \\
\hline $\begin{array}{l}\text { Checherita- } \\
\text {-Westphal } \\
\text { i Rother } \\
\text { (2012) }\end{array}$ & $\begin{array}{l}\text { modele z efekta- } \\
\text { mi stałymi (FE) } \\
\text { oraz model ze } \\
\text { zmiennymi in- } \\
\text { strumentalnymi } \\
\text { (IV REG) }\end{array}$ & 1970-2010 & $\begin{array}{l}12 \text { rozwiniętych } \\
\text { krajów strefy euro }\end{array}$ & - & - & $\begin{array}{l}81,2- \\
104,6\end{array}$ \\
\hline $\begin{array}{l}\text { Chen, Yao, } \\
\text { Hu, Lin } \\
(2016)\end{array}$ & $\begin{array}{l}\text { modele regresji } \\
\text { z wygładzaniem } \\
\text { (PSTR) }\end{array}$ & 1991-2014 & $\begin{array}{l}65 \text { krajów, brak } \\
\text { podziału grupy } \\
\text { badawczej }\end{array}$ & 59,7 & - & - \\
\hline $\begin{array}{l}\text { Egert } \\
(2015)\end{array}$ & $\begin{array}{l}\text { modele } \\
\text { bayesowskie }\end{array}$ & 1946-2009 & $\begin{array}{l}29 \text { krajów OECD, } \\
\text { brak podziału } \\
\text { grupy badawczej }\end{array}$ & $20-60$ & - & - \\
\hline $\begin{array}{l}\text { Gómez- } \\
\text {-Puig, So- } \\
\text { svilla-Rivero } \\
(2015)\end{array}$ & $\begin{array}{l}\text { testy przyczyno- } \\
\text { wości w sensie } \\
\text { Grangera }\end{array}$ & 1980-2013 & $\begin{array}{l}11 \text { rozwiniętych } \\
\text { krajów strefy euro }\end{array}$ & - & - & 56-103 \\
\hline $\begin{array}{l}\text { Karadam } \\
(2018)\end{array}$ & $\begin{array}{l}\text { modele regresji } \\
\mathrm{z} \text { wygładzaniem } \\
\text { (PSTR) } \\
\end{array}$ & 1970-2012 & $\begin{array}{l}23 \text { kraje rozwinięte } \\
\text { i } 113 \text { krajów roz- } \\
\text { wijających się }\end{array}$ & - & 88,2 & 106,6 \\
\hline $\begin{array}{l}\text { Mencinger, } \\
\text { Aristovnik, } \\
\text { Verbic } \\
(2014)\end{array}$ & $\begin{array}{l}\text { modele z efekta- } \\
\text { mi stałymi (FE) } \\
\text { oraz modele } \\
\text { uogólnionej me- } \\
\text { tody momentów } \\
\text { (GMM IV) }\end{array}$ & 1980-2010 & $\begin{array}{l}15 \text { krajów starej } \\
\text { UE oraz } 10 \text { krajów } \\
\text { nowej UE }\end{array}$ & - & 53,5 & $\begin{array}{l}79,6- \\
94,1\end{array}$ \\
\hline $\begin{array}{l}\text { Mencinger, } \\
\text { Aristovnik, } \\
\text { Verbic } \\
(2015)\end{array}$ & $\begin{array}{l}\text { modele z efekta- } \\
\text { mi stałymi (FE) } \\
\text { oraz modele } \\
\text { uogólnionej me- } \\
\text { tody momentów } \\
\text { (GMM IV) }\end{array}$ & 1980-2010 & $\begin{array}{l}24 \text { kraje rozwinięte } \\
\text { oraz } 12 \text { krajów } \\
\text { rozwijających się }\end{array}$ & - & 44,5 & $\begin{array}{l}89,5- \\
93,5\end{array}$ \\
\hline $\begin{array}{l}\text { Reinhart, } \\
\text { Rogoff } \\
(2010)\end{array}$ & $\begin{array}{l}\text { analiza statystyk } \\
\text { opisowych - śred- } \\
\text { niej i mediany }\end{array}$ & 1946-2009 & $\begin{array}{l}20 \text { krajów rozwi- } \\
\text { niętych i } 24 \text { kraje } \\
\text { rozwijające się }\end{array}$ & - & 60 & 90 \\
\hline
\end{tabular}

Źródło: opracowanie własne.

Znaczące różnice między bezpiecznymi poziomami zadłużenia mogą czasami wynikać z różnic metodologicznych, odmiennych prób czasowych oraz doboru różnych obiektów. Ponadto autorzy badań, dokonując rozróżnienia próby badawczej na kraje rozwijające się i rozwinięte, zwykle nie definiują tych pojęć. Konsekwencją tego może być wybranie do jednej kategorii krajów o znacząco różnym poziomie rozwoju gospodarczego. 


\section{Podsumowanie}

Wpływ wysokości zadłużenia na PKB jest przedmiotem sporów wielu ekonomistów i - ze względu na trudności metodyczne w jego badaniu - nie jest jednoznacznie interpretowany. Problemów przysparzają często kwestie związane z nieliniowością, odwrotną przyczynowością oraz endogenicznością, powodując, że dotychczasowe badania empiryczne są obarczone pewnymi wątpliwościami natury metodologicznej, utrudniającymi interpretację rzeczywistego wpływu długu publicznego na wzrost gospodarczy. W niniejszym opracowaniu posłużono się dwiema metodami analizy - analizą statystyk opisowych oraz analizą ekonometryczną. Pierwsza z nich miała na celu zweryfikowanie współistnienia zjawisk niskiego długu publicznego oraz wysokiego tempa rozwoju gospodarczego. Analiza ekonometryczna miała za zadanie sprawdzenie, czy między tymi wskaźnikami zachodzi związek przyczynowo-skutkowy. W celu ograniczenia wątpliwości związanych z odwrotną przyczynowością i endogenicznością jako zmienne niezależne w prezentowanych modelach ekonometrycznych włączono opóźnione wartości wskaźników długu publicznego. Dzięki założeniu, że bieżący poziom wzrostu PKB per capita nie powinien mieć wpływu na opóźniony poziom wskaźnika długu publicznego, został ograniczony problem odwrotnej przyczynowości. Stosunek długu publicznego do PKB w roku poprzedzającym jest skorelowany ze swoją wartością w roku bieżącym i jako tak dobrana zmienna w pewnym stopniu ogranicza problem endogeniczności. Należy zaznaczyć, że nie opracowano jeszcze metody eliminacji tych dwóch problemów, które nie budzą jednak wątpliwości niektórych badaczy (por. np. Reinhart i in. 2012).

$\mathrm{Na}$ podstawie analizy uwzględniającej pewne opisane wcześniej trudności metodyczne można wyróżnić kilka kluczowych wniosków. Porównując statystyki opisowe, należy stwierdzić, że kraje o najwyższym wzroście gospodarczym w latach 1996-2017 nie zawsze charakteryzowały się niską relacją długu publicznego do PKB, np. Polska i Słowacja, w przypadku których wskaźnik długu publicznego przekraczał średnią, odnotowywały relatywnie wysokie średnie tempo wzrostu gospodarczego - na poziomie powyżej 4\%. Przeprowadzona weryfikacja okazała się bardziej jednoznaczna w odniesieniu do poszczególnych obserwacji, a nie krajów. Obserwacje, w przypadku których odnotowano wskaźnik długu publicznego na poziomie poniżej $30 \%$, cechowały się wyższym średnim oraz środkowym tempem wzrostu gospodarczego niż obserwacje z większymi wskaźnikami długu publicznego sklasyfikowanymi w przedziałach odpowiednio 31-60\% oraz powyżej $60 \%$. Uzyskane wyniki pozwalają potwierdzić, że w badanej próbie niskiemu poziomowi zadłużenia publicznego zazwyczaj odpowiadał wyższy przeciętny wzrost gospodarczy. Nie potwierdza to jednak hipotezy, że wysoki dług publiczny jest przyczyną niskiego wzrostu gospodarczego. W celu określenia związku przyczynowo-skutkowego pomiędzy tymi kategoriami skonstruowano cztery modele ekonometryczne z opóźnionymi wielkościami zadłużenia 
publicznego oraz kwadrat zadłużenia publicznego. Zmienną kwadrat zadłużenia publicznego dodano, zakładając, że relacja pomiędzy zadłużeniem a wzrostem gospodarczym nie jest liniowa. Za pomocą przeprowadzonych estymacji wykazano, że wielkość relacji długu publicznego do PKB, po której przekroczeniu dług publiczny zaczyna negatywnie oddziaływać na tempo wzrostu gospodarczego, waha się w przedziale $67,3-77 \%$. Należy jednak przy tym zauważyć, że jedynie trzy spośród 11 krajów przekroczyły przynajmniej najniższy próg. Można więc założyć, że większość badanych krajów Europy Środkowo-Wschodniej nie jest jeszcze zadłużona $\mathrm{w}$ takim stopniu, żeby sama wysoka wartości relacji między długiem publicznym a PKB miała negatywny wpływ na przyrost PKB per capita.

\section{Bibliografia}

Afonso A., Jalles J.T. (2013), Growth and productivity: The role of government $d e b t$, ,International Review of Economics and Finance”, $\mathrm{nr} 25$.

Baharumshah A.Z., Soon S.V., Lau E. (2017), Fiscal sustainability in an emerging market economy: When does public debt turn bad?, „Journal of Policy Modeling", nr 39.

Baum A., Checherita-Westphal C., Rother P. (2013), Debt and growth: New evidence for the euro area, „Journal of International Money and Finance”, nr 32.

Bilan I. (2015), Economic consequences of public debt. The case of Central and Eastern European countries, „Eurint”, nr 2.

Bilan I., Julian I. (2015), Public debt and economic growth: A two-sided story, „International Journal of Economic Sciences”, nr 2.

Cecchetti S., Zampolli F. (2011), The real effects of debt, „BIS Working Papers”, nr 52.

Checherita-Westphal C., Rother P. (2012), The impact of high government debt on economic growth and its channels: An empiric linvestigation for the euro area, „European Economic Review”, nr 56.

Chen C., Yao S., Hu P., Lin Y. (2017), Optimal government investment and public debt in an economic growth model, „China Economic Review”, $\mathrm{nr} 45$.

Cordella T., Ricci L.A., Ruiz-Arranz M. (2005), Debt overhang or debt irrelevance? Revisiting the Debt-Growth Link, „IMF Working Paper”, $\mathrm{nr}$ 5/223.

Eberhardt M. (2017), Nonlinearities in the relationship between debt and growth: (no) evidence from over two centuries, „Macroeconomic Dynamics”, nr 23.

Eberhardt M., Presbitero A. (2015), Public debt and growth: Heterogeneity and non-linearity, „Journal of International Economics”, nr 97.

Égert B. (2015), Public debt, economic growth and nonlinear effects: Myth or reality?, „Journal of Macroeconomics”, nr 43.

Gómez-Puig M., Sosvilla-Rivero S. (2015), The causal relationship between debt and growth in EMU countries, „Journal of Policy Modeling”, $\mathrm{nr} 37$. 
Gómez-Puig M., Sosvilla-Rivero S. (2017), Public debt and economic growth: Further evidence for the euro area, „ICEI Working Papers”, nr 9.

Imbs J., Ranciere R. (2005), The overhang hangover, „Economic Working Papers", $\mathrm{nr} 878$.

Karadam D.Y. (2018), An investigation of nonlinear effects of debt on growth, „The Journal of Economic Asymmetries”, nr 18.

Karagöz M., Demirhan A. (2016), Is really debt a man's whip? „Procedia Economics and Finance", nr 38.

Kempa B., Sadat K.N. (2017), Spillover effects of debt and growth in the euro area: Evidence from a GVAR model, „International Review of Economics and Finance".

Kumar M., Woo J. (2010), Public debt and growth, „IMF Working Paper”, nr 10/174.

Mencinger J., Aristovnik A., Verbic M. (2014), The impact of growing public debt on economic growth in the European Union, „Amfiteatru Economic Journal", nr 16.

Mencinger J., Aristovnik A., Verbic M. (2015), Revisiting the role of public debt in economic growth: the case of OECD countries, „Engineering Economics”, $\mathrm{nr} 1$.

Misztal P. (2011), Dlug publiczny i wzrost gospodarczy w krajach czlonkowskich Unii Europejskiej, Polityki Europejskie, „Finanse i Marketing”, nr 5 (54).

Mitze T., Matz F. (2015), Public debt and growth in German federal states: What can Europe learn? „Journal of Policy Modeling”, nr 37.

Moore W., Thomas C. (2008), A meta-analysis of the relationship between debt and growth, „International Journal of Development Issues”, nr 9.

Owusu-Nantwi V., Erickson C. (2016), Public debt and economic growth in Gha$n a$, ,African Development Review”, nr 28.

Panizza U., Presbitero A. (2014), Public debt and economic growth: Is there a causal effect? „Journal of Macroeconomics”, $\mathrm{nr} 41$.

Patillo C., Poirson H., Ricci L.A. (2011), External debt and growth, „Review of Economic and Institutions", $\mathrm{nr} 3$.

Reinhart C., Rogoff K. (2010), Growth in a time of debt, „American Economic Review", nr 2.

Reinhart C., Reinhart V., Rogoff K. (2012), Debt overhangs: Past and prestent, NBER ,Working Paper”, nr 18015.

Reinhart C., Reinhart V., Rogoff K. (2012), Public debt overhangs: Advanced-economy episodes since 1800, „Journal of Economic Perspectives”, $\mathrm{nr} 3$.

Siwińska-Gorzelak J. (2015), Dlug publiczny a wzrost gospodarczy, Wydawnictwo Naukowe Scholar, Warszawa.

Teles V., Mussolini C. (2014), Public debt and the limits of fiscal policy to increase economic growth, „European Economic Review”, nr 66. 


\section{Streszczenie}

W artykule podjęto próbę określenia wpływu wysokości zadłużenia publicznego na wzrost PKB per capita w krajach Europy Środkowo-Wschodniej w latach 1996-2017. Przeprowadzona analiza dowiodła, że wysokie zadłużenie publiczne jest skorelowane z niskim tempem wzrostu gospodarczego. W celu zweryfikowania, czy współistnienie tych kategorii ekonomicznych ma charakter przyczynowo-skutkowy, dokonano estymacji parametrów dla opóźnionych wartości relacji długu do PKB oraz opóźnionego kwadratu tej zmiennej. Posłużono się czterema rodzajami modeli ekonometrycznych (KMNK, model z efektami stałymi, Uogólniona Metoda Momentów systemowa oraz UMM pierwszych różnic). W wyniku wyliczeń otrzymano teoretyczne progowe wartości maksymalnego stosunku zadłużenia publicznego do PKB per capita plasujące się między 67,3\% a 77\%. W odniesieniu do tak wyestymowanych wartości jedynie Słowenia, Chorwacja i Węgry osiągnęły niebezpieczny poziom długu publicznego.

Slowa kluczowe: dług publiczny, wzrost gospodarczy, polityka fiskalna

\section{Summary}

The impact of public debt on the dynamics of economic growth in Central-Eastern European countries

The paper concerns the impact of debt on economic growth in CEE countries for the years 1996-2017. The analysis has shown that there is a coexistence of high public debt and low economic growth. To verify whether the coexistence of these economic categories is causal, the estimation has delayed values of the debt to GDP ratio and the square of that variable. The analysis included four types of econometric models: OLS, GMM first difference, system GMM and fixed effects. As a result of our calculations, the thresholds for the maximum public debt-to-GDP ratio per capita ranged between $67.3 \%$ and $77 \%$. For such computed thresholds only Slovenia, Croatia and Hungary have reached a dangerous level of public debt.

Keywords: public debt, economic growth, fiscal policy

JEL: E62, H60, O47 